\title{
Characteristics of multi-annual variation of precipitation in areas particularly exposed to extreme phenomena. Part 2. The upper and middle Oder river basin
}

\author{
Bernard Twaróg ${ }^{1, *}$ \\ ${ }^{1}$ Faculty of Environmental Engineering, Cracow University of Technology, Warszawska Str. 24, \\ 31-155 Cracow, Poland
}

\begin{abstract}
The study contains an analysis of precipitation, covering multiple profiles and based on the GPCC database that provides monthly mean values for the territory upper and middle Oder catchment. The analysis includes data for the period 1901-2010 with a spatial resolution of $0.5^{\circ} \times{ }^{\circ} 0.5^{\circ}$ of geographic longitude and latitude. The following sections include a data analysis in monthly profiles and hydrological cycle profiles, taking into account hydrological summer and hydrological winter. A cluster analysis is also included, with drought and flood periods indicated. The periodical nature of precipitation is assessed and the trends in climate changes calculated.
\end{abstract}

\section{Introduction}

This study contains the second part of regional analyses performed for selected areas in the Vistula and Oder drainage basins. The first part contained an analysis of precipitation variation in the upper Vistula area over multiple years. This study discusses the results of analyses covering the variation range of precipitation characterised by its mean monthly values for the upper and middle Oder drainage basin over a period of more than 100 years.

The Oder drainage basin occupies $118,861 \mathrm{~km}^{2}$ (Ausschuss, 1896). The first systematic study on the Oder (Ausschuss, 1896) distinguishes: the springs of the Oder, the upper Oder, middle Oder and lower Oder. The upper Oder is defined as the reach between Olza and the confluence with the Widawa, at the confluence with the Nysa Kłodzka. The upper Oder is divided into its upper and lower course. The middle Oder is defined as the reach from the confluence with the Widawa to the confluence with the Warta. The most recent studies by the International Commission for the Protection of the Oder River against Pollution (IKSO, 1999) define the area of upper Oder as the reach from the river springs to the confluence with the Nysa Kłodzka, and the area of middle Oder as the entire reach from the Nysa Kłodzka to the confluence with Warta. The upper and middle Oder drainage basin occupies $53,536 \mathrm{~km}^{2}[1,2]$, or $53467 \mathrm{~km}^{2}$ in the system of the Map of Hydrographic Divides in Poland. Precipitation ranging from 500 to $600 \mathrm{~mm}$ is recorded in the largest part of the

\footnotetext{
* Corresponding author: btwarog@pk.edu.pl
} 
drainage basin and from 1,000 to $1,300 \mathrm{~mm}$ on mountain ridges. July is the month of the most intense precipitation and the minimum values of precipitation are recorded in February [3].

\section{Estimating water resources for the purposes of regional planning}

The study is aimed to address the need for characteristics of long-term sequences of totals and average monthly values of precipitation in areas particularly exposed to extreme events. The need for such analyses is also expressed in the documents developed within the United Nations Framework Convention on Climate Change. The documents indicate that policies should be adapted to the ongoing climate changes, by performing regional and local analyses of those changes, as necessary to develop scenarios designed to compensate their effects. The analyses of climate changes performed at a regional level indicate a strong correlation between the changes and anthropogenic impact, and draw attention to an adverse trend: a constant polarisation of meteorological phenomena, corresponding to intense and chaotic activity of man.

The purposefulness of regional analyses is confirmed by the trends in volumes of water resources (Table 1), indicating not only the range of changes but also their direction. The upper Vistula drainage basin is characterised by upward trends while the upper and middle Oder drainage basin - by downward trends (about $-13 \mathrm{Mm}^{3} /$ year). The situation becomes even more complicated with a growing level of detail, in calculations of water balances in drainage basins, as demonstrated in the last section of this study.

Table 1. A statement of annual balances of water resources in the upper Vistula and the upper and middle Oder for the period 1901-2010 [4].

\begin{tabular}{|c|c|c|c|c|c|}
\hline $\begin{array}{c}\text { Region of water } \\
\text { resources } \\
\text { assessment }\end{array}$ & $\begin{array}{c}\text { Area } \\
{\left[\mathbf{k m}^{2}\right]}\end{array}$ & $\begin{array}{c}\text { Total of precipitation p.a. } \\
\text { mean values for the long- } \\
\text { term period[mm], } \\
\text { GPCC data }\end{array}$ & $\begin{array}{c}\text { Volume } \\
\text { V[billion } \\
\left.\mathbf{m}^{\mathbf{3}} / \mathbf{y e a r}\right]\end{array}$ & $\begin{array}{c}\text { Trend } \\
{[\mathbf{m m} / \mathbf{y e a r}]}\end{array}$ & $\begin{array}{c}\text { Trend } \\
{[\text { [million }} \\
\left.\mathbf{m}^{\mathbf{3}} / \mathbf{y e a r}\right]\end{array}$ \\
\hline Poland & 312,679 & 619.1 & 193.58 & 0.002 & 0.625 \\
\hline upper Vistula & 43,109 & 742.3 & 32.00 & 0.294 & 12.674 \\
\hline $\begin{array}{c}\text { upper and middle } \\
\text { Oder }\end{array}$ & 53,467 & 671.8 & 35.92 & -0.236 & -12.618 \\
\hline
\end{tabular}

\section{Characteristics of data}

The GPCC data representing total precipitation volumes in individual months in the period 1901-2010 [5], with a spatial resolution of $0.5^{\circ} \times 0.5^{\circ}$ of geographic longitude and latitude, converted to the analysed area of Polish catchment basin. Thus a sequence of monthly precipitation values was obtained that is analysed in this study. The calculated sequence values were subject to a simple statistical analysis in order to determine the basic statistics: the minimum and maximum values, the mean value, standard deviation of the sample and the value of the coefficient of variation [4].

\section{Selected analyzes for the upper and middle Oder area, data in the period 1901-2010}

The calculated sequences of monthly precipitation in the long-term period from 1901 to 2010 were subject to a statistical analysis aimed to determine the basic statistics: the 
minimum and maximum values, the mean value, standard deviation of the sample and the value of the coefficient of variation. The data is analysed using profiles modelled for individual calendar years and for hydrological years divided into hydrological summers and hydrological winters. The analyses of monthly precipitation cover the years 1901-2010, and the analyses of cumulative monthly total values of precipitation cover the hydrological years 1902-2010 [4].

The analysed area is shown in Figure 1 with the upper and middle Oder drainage basin marked. The results of analyses include the total for the upper and middle Oder area.

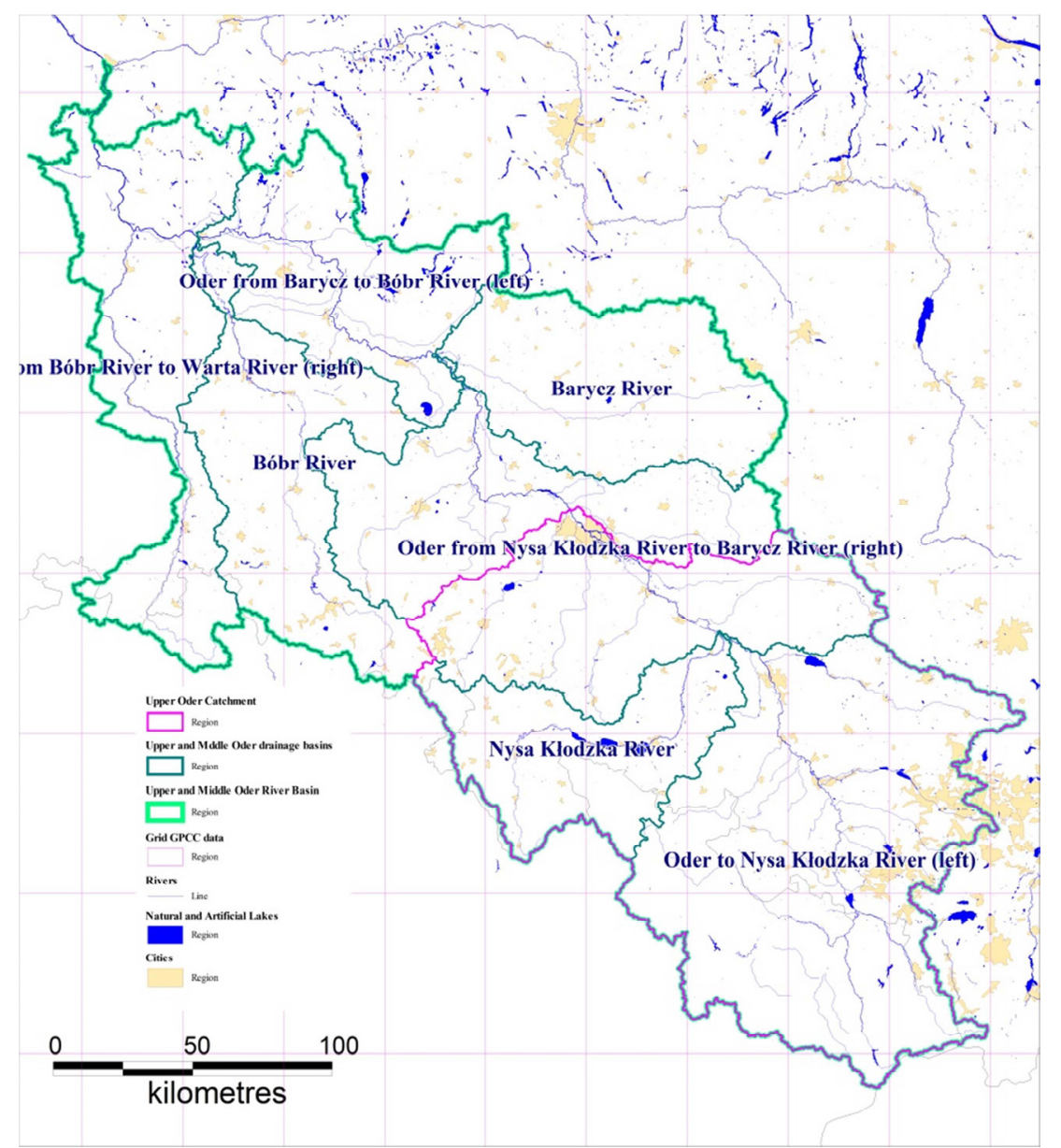

Fig. 1. The upper and middle Oder river basin and drainage basins on the grid GPCC data.

Table 2 contains the values of statistics in monthly profiles. The minimum values of total precipitation in the analysed period 1901-2010 occurred in November (a level of about $3.5 \mathrm{~mm}$ ) and the maximum values occurred in July $(261 \mathrm{~mm})$. The greatest total of precipitation may be expected in July and the minimum total - in February. The greatest variation of precipitation occurs in October, and the minimum one in June. An analysis of the mean value, deviation and coefficient of variation (the minimum value) of the total of precipitation leads to the conclusion that June is a rainy month in the upper and middle Oder drainage basin. 
Table 2. A statement of monthly precipitation values and selected statistics for the period 1901-2010 in the upper and middle Oder river basin.

\begin{tabular}{|l|c|c|c|c|c|c|c|c|c|c|c|c|}
\hline & \multicolumn{9}{|c|}{ Months of the calendar year, Statistics } \\
\hline & 'I' & 'II' & 'III' & 'IV' & 'V' & 'VI' & 'VII' & 'VIII' & 'IX' & 'X' & 'XI' & 'XII' \\
\hline Min, [mm] & 11.32 & 7.89 & 7.99 & 5.53 & 18.18 & 15.78 & 19.52 & 25.88 & 5.14 & 3.54 & 7.35 & 6.31 \\
\hline Max, [mm] & 98.11 & 99.38 & 96.12 & 107.05 & 159.97 & 211.92 & 260.93 & 181.59 & 122.93 & 185.26 & 104.05 & 105.78 \\
\hline Mean, [mm] & 40.05 & 35.70 & 38.90 & 45.99 & 68.63 & 77.26 & 88.16 & 83.53 & 53.84 & 48.09 & 48.13 & 43.82 \\
\hline $\begin{array}{l}\text { Standard deviation } \\
\text { of the sample, } \\
\text { [mm] }\end{array}$ & 16.61 & 15.62 & 18.46 & 16.38 & 25.14 & 27.15 & 38.31 & 31.22 & 26.09 & 29.73 & 18.45 & 18.94 \\
\hline $\begin{array}{l}\text { Coefficient } \\
\text { of variation, } \mathrm{C}_{\mathrm{v}},[-]\end{array}$ & 0.41 & 0.44 & 0.47 & 0.36 & 0.37 & 0.35 & 0.43 & 0.37 & 0.48 & 0.62 & 0.38 & 0.43 \\
\hline
\end{tabular}

The results contained in Table 3 refer to hydrological cycles. The values of total precipitation in the summer and winter seasons indicate a great variation of relations between those values. The ratio of the maximum total of precipitation in the summer season to the minimum total in the summer season $(620 \mathrm{~mm} / 160 \mathrm{~mm})$ equals about 3.9. The ratio of the maximum total of precipitation in the winter season to the minimum total in the summer season $(400 \mathrm{~mm} / 230 \mathrm{~mm})$ equals about 1.7 .

Table 3. A statement of statistics for total monthly precipitation, cumulative for a hydrological year and in the summer and winter seasons in the period 1901-2010 in the upper and middle Oder river basin.

\begin{tabular}{|l|c|c|c|c|c|c|c|c|c|c|c|c|c|c|}
\hline & \multicolumn{9}{|c}{ Months of the hydrological year } & \multicolumn{4}{c|}{ Hydrological seasons } \\
\cline { 2 - 15 } & 'XI' & 'XII' & 'I' & 'II' & 'III' & 'IV' & 'V' & 'VI' & 'VII' & 'VIII' & 'IX' & 'X' & $\begin{array}{c}\text { Winter } \\
(\text { XI-IV) }\end{array}$ & $\begin{array}{c}\text { Summer } \\
(\text { V-X) }\end{array}$ \\
\hline Min, [mm] & 7.3 & 35.6 & 60.0 & 93.3 & 109.1 & 161.1 & 205.6 & 272.9 & 343.9 & 388.1 & 422.0 & 478.5 & 161.1 & 230.6 \\
\hline Max, [mm] & 104.1 & 188.3 & 271.9 & 345.4 & 373.3 & 399.5 & 488.3 & 553.1 & 682.2 & 778.8 & 838.9 & 898.4 & 399.5 & 619.5 \\
\hline Mean, [mm] & 47.7 & 91.4 & 131.6 & 167.4 & 206.0 & 251.8 & 320.6 & 397.9 & 486.4 & 569.8 & 623.8 & 671.8 & 251.8 & 420.0 \\
\hline $\mathrm{S}_{\mathrm{d},}[\mathrm{mm}]$ & 18.0 & 26.2 & 33.3 & 36.2 & 41.8 & 42.5 & 49.2 & 55.6 & 68.1 & 77.6 & 86.0 & 92.1 & 42.5 & 77.7 \\
\hline $\mathrm{C}_{\mathrm{v}},[-]$ & 0.377 & 0.286 & 0.253 & 0.216 & 0.203 & 0.169 & 0.153 & 0.140 & 0.140 & 0.136 & 0.138 & 0.137 & 0.169 & 0.185 \\
\hline
\end{tabular}

\subsection{A taxonomic analysis}

The results of clustering monthly precipitation in the years 1901-2010 described by mean values, standard deviations and coefficients of variation using the Ward's method are represented as a cluster tree [4]. The analysis focuses on a detailed representation of two extreme clusters identified as drought and flood periods in the upper and middle Oder area.

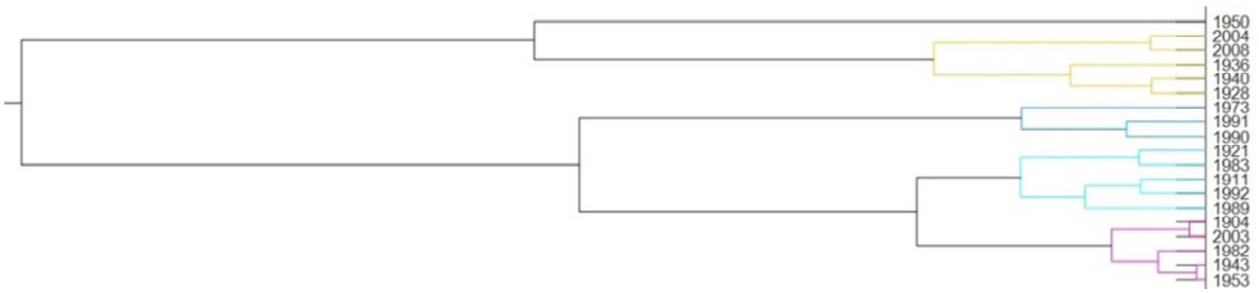

Fig. 2. The cluster of "dry years" classified according to mean monthly precipitation in the upper and middle Oder river basin. 


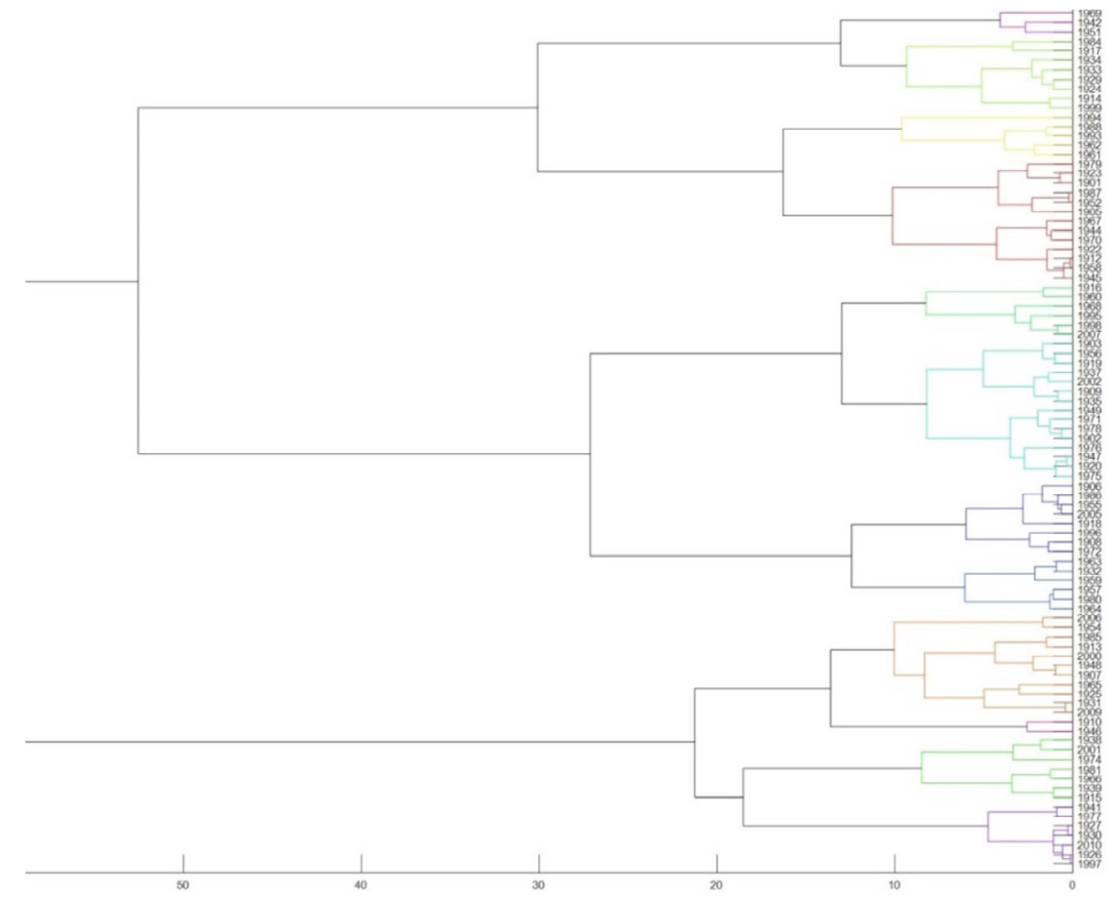

Fig. 3. The cluster of "wet years" classified according to mean monthly precipitation in the upper and middle Oder river basin.

The cluster of "wet years" (Figure 3) represents the levels of mean monthly precipitation in the upper and middle Oder drainage basin ranging from 44.01 to $75.80 \mathrm{~mm}$, standard deviation ranging from 20.65 to $64.58 \mathrm{~mm}$ and the coefficient of variation from 0.33 to 1.01 . The extreme calendar years characterised by the greatest mean values, standard deviation and coefficients of variation include: 1997, 1926, 2010, 1930, 1927, $1977,1941, \ldots$ The cluster includes 91 years in total, i.e. about $83 \%$ of the analysed period.

In contrast, the cluster of drought years (Figure 2) includes the years when the values of mean monthly precipitation in the upper and middle Oder drainage basin ranged from 40.63 to $52.17 \mathrm{~mm}$, standard deviation ranged from 13.87 to $25.63 \mathrm{~mm}$ and the coefficient of variation from 0.31 to 0.63 . The following calendar years are included in the cluster: 1953, 1943, 1982, 2003, 1904, 1989, 1992, 1911, 1983, 1921, 1990, 1991, 1973, 1928, 1940, $1936,2008,2004,1950$. The cluster includes 19 years in total, i.e. about $17 \%$ of the analysed period.

\subsection{Periodicity of precipitation}

The periodicity of precipitation in the upper and middle Oder catchment basin was assessed using signal processing theory with a harmonic analysis applied. The procedures necessary to calculate the values of predominating frequencies were developed in Matlab. The inverses of those values represent the predominating period of repeatability of an event. The analysis was completed for various profiles of the analysed dataset [4].

The periodicity of monthly precipitation calculated using monthly profiles of calendar years in the analysed period 1901-2010 may be described as follows (Table 4): October is characterised by a long predominating period of repeatability of 36 years while predominating periods of repeatability for the remaining months amount to $2.1-7.79$ years. 
The periods of repeatability: 2.1 years for minimum values, 3.89 years for maximum values, and 3.21 years for medium values.

Table 4. A statement of periodicity values (inverses of predominating frequencies) for mean monthly precipitation sequences in the period 1901-2010 by months in the upper and middle Oder river.

\begin{tabular}{|c|c|c|c|c|c|c|c|c|c|c|c|c|c|c|c|c|c|}
\hline \multirow{2}{*}{$\begin{array}{c}\text { Analysed } \\
\text { sequence } \\
\text { profile }\end{array}$} & \multicolumn{12}{|c|}{ Months of the calendar year } & \multicolumn{5}{|c|}{ Periodicity of statistics } \\
\hline & 'I' & 'II' & 'III' & 'IV' & ' $\mathbf{V}^{\prime}$ & 'VI' & 'VII' & 'VIII' & 'IX' & 'X' & 'XI' & 'XII' & Min & Max & Avg & $S_{d}$ & $C_{v}$ \\
\hline $\begin{array}{l}\text { Predominating } \\
\text { period in years }\end{array}$ & 5.45 & 2.42 & 2.10 & 2.37 & 3.21 & 2.66 & 3.89 & 7.79 & 2.37 & 36.33 & 2.10 & 6.41 & 2.10 & 3.89 & 3.21 & 9.91 & 4.19 \\
\hline
\end{tabular}

The periodicity of total monthly precipitation calculated using hydrological year profiles in the analysed period 1902-2010 is characterised by several predominating periods of 2, 3, 5 and 10 years. In an analysis of predominating frequencies, the 3 -year periods for the months November-February are clearly identifiable.

Table 5. A statement of periodicity values (inverses of predominating frequencies) for sequences of cumulative total of mean monthly precipitation in the period 1901-2010 by hydrological years in the upper and middle Oder river basin.

\begin{tabular}{|c|c|c|c|c|c|c|c|c|c|c|c|c|}
\hline \multirow{3}{*}{$\begin{array}{l}\text { Analysedsequence } \\
\text { profile }\end{array}$} & \multicolumn{12}{|c|}{ Months of the hydrological year } \\
\hline & 'XI' & 'XII' & 'I' & 'II' & 'III' & 'IV' & ' $\mathbf{\prime}$ & 'VI' & 'VII' & 'VIII' & 'IX' & 'X' \\
\hline & \multicolumn{12}{|c|}{ [years] } \\
\hline $\begin{array}{l}\text { Predominating } \\
\text { period in years }\end{array}$ & 3.00 & 3.00 & 3.00 & 3.00 & 2.16 & 2.08 & 3.48 & 4.91 & 4.91 & 9.82 & 9.82 & 4.91 \\
\hline
\end{tabular}

The periodicity of total monthly precipitation calculated using hydrological summer and hydrological winter profiles in the analysed period 1902-2010 equals 2.08 years for the winter season and 2.35 years for the summer season.

\subsection{Premises for an analysis of climate changes observed in precipitation}

The image of trend in climate changes obtained using total monthly precipitation profiles for the hydrological year is described by linear equations with indicated boundary values of coefficients determined at a 5\% significance level [4]. The linear trend form is characterised mainly by a slope [mm/year]. The total of precipitation in the analysed period of 109 years (1902-2010) reflects a negative trend of $-0.236 \mathrm{~mm} /$ year. The lower and upper limits of ranges for a $95 \%$ confidence interval are: $-0.795 \mathrm{~mm} /$ year and $0.903 \mathrm{~mm} /$ year.

The trend reflecting climate changes in a calendar year, obtained using monthly precipitation profiles (Table 6), is described by linear equations with indicated boundary values of coefficients determined at a 5\% significance level. The slope values are both negative and positive for the analysed period 1901-2010. The months of January, April, June, August, October and November are characterised by a decreasing trend in precipitation while the remaining months by a positive trend. The values vary between 0.129 in October and $+0.108 \mathrm{~mm} / \mathrm{month}$ in July. 
Table 6. Values of parameters of the linear trend in monthly precipitation in a calendar year in the analysed period in the upper and middle Oder river basin.

\begin{tabular}{|c|c|c|c|c|c|c|c|c|c|c|c|c|c|c|c|c|c|}
\hline & \multicolumn{12}{|c|}{ Months of the calendar year } & \multicolumn{5}{|c|}{ Trend of statistics } \\
\hline & 'I' & 'II' & 'III' & 'IV' & ' $\mathbf{C}^{\prime}$ & 'VI' & 'VII & 'VIII' & IX' & 'X' & 'XI & 'XII' & Min & Max & Avg & $S_{d}$ & $C_{v}$ \\
\hline & \multicolumn{12}{|c|}{$[\mathrm{mm} / \mathrm{month}]$} & \multicolumn{5}{|c|}{$[-]$} \\
\hline 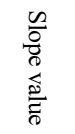 & 总 & ষి & $\stackrel{\mathscr{B}}{\mathrm{B}}$ & $\stackrel{b}{0}$ & 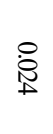 & ؛े & $\stackrel{\circ}{\triangleright}$ & 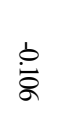 & ஜ & 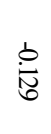 & 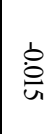 & $\underset{\mathrm{d}}{\stackrel{8}{0}}$ & 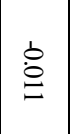 & $\begin{array}{l}\stackrel{8}{\mathscr{\infty}} \\
\stackrel{0}{2}\end{array}$ & $\begin{array}{l}\dot{0} \\
\stackrel{\circ}{\sigma}\end{array}$ & $\begin{array}{l}\stackrel{8}{0} \\
\mathbb{8}\end{array}$ & $\begin{array}{l}\text {. } \\
\text { \&̊े } \\
\text { 志 }\end{array}$ \\
\hline 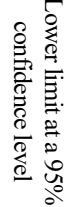 & $\stackrel{b}{\omega}$ & 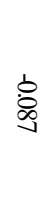 & 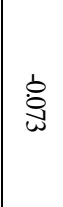 & $\stackrel{b}{9}$ & 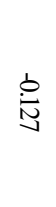 & $\stackrel{b}{\grave{\omega}}$ & 힝 & 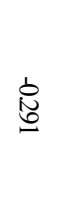 & 客 & $\begin{array}{l}\dot{d} \\
\text { 岕 }\end{array}$ & 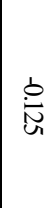 & $\frac{b}{8}$ & 它 & $\stackrel{\dot{0}}{0}$ & @் & $\begin{array}{l}\dot{0} \\
\text { ర్ల }\end{array}$ & $\begin{array}{l}1 \\
8 \\
8 \\
\text { 엉 }\end{array}$ \\
\hline 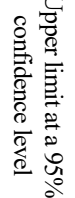 & \&̊․ & : & $\stackrel{\circ}{E}$ & 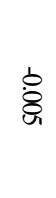 & $\stackrel{\ominus}{\vec{A}}$ & $\stackrel{\circ}{\circ}$ & 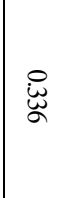 & \&̊․ & $\stackrel{\circ}{\circ}$ & $\stackrel{8}{\$}$ & : & 응 & 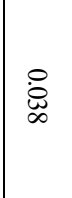 & $\begin{array}{l}\text { 吼 } \\
\text { }\end{array}$ & $\stackrel{\text { }}{\stackrel{\dot{D}}{0}}$ & ஜ் & $\stackrel{\circ}{\stackrel{8}{\Xi}}$ \\
\hline
\end{tabular}

\section{The upper and middle Oder drainage basins}

A detailed analysis of mean precipitation in the upper and middle Oder area over the long period was completed for the following water balance basins (Figure 1): the Oder from the Bóbr to the Warta (p), the Bóbr, the Oder from the Barycz to the Bóbr (1), the Barycz, the Oder from the Nysa Kłodzka to the Barycz (p), the Nysa Kłodzka, the Oder to the Nysa Kłodzka (1). The analysed drainage basins are also identified in the Map of Hydrographic Divides in Poland developed by the Institute of Meteorology and Water Management, recommended for and used in analyses performed as part of broadly understood water management.

The values of precipitation trends in the water-balance basins of the upper and middle Oder (Table 7) confirm a spatial polarisation of precipitation phenomena, in addition to the temporal polarisation indicated above (Table 2 and Table 3). The trends show an urgent need for scenarios designed to compensate extreme phenomena of flood and drought.

Table 7. A statement of annual balances of water resources in upper and middle Oder drainage basins.

\begin{tabular}{|c|c|c|c|c|c|c|}
\hline $\begin{array}{c}\text { Region of water } \\
\text { resources assessment }\end{array}$ & $\begin{array}{c}\text { Kod ID_HYD } \\
\text { according to MPHP } \\
\text { database system }\end{array}$ & $\begin{array}{c}\text { Area } \\
{\left[\mathbf{k m}^{\mathbf{2}}\right]}\end{array}$ & $\begin{array}{c}\text { Total of precipitation p.a. } \\
\text { mean values for the long-term } \\
\text { period[mm], GPCC data }\end{array}$ & $\begin{array}{c}\text { Volume V } \\
{\left[\begin{array}{l}\text { [billion } \\
\left.\mathbf{m}^{\mathbf{3}} / \mathbf{y e a r}\right]\end{array}\right.}\end{array}$ & $\begin{array}{c}\text { Trend } \\
{[\mathbf{m m} / \mathbf{y e a r}]}\end{array}$ & $\begin{array}{c}\text { Trend } \\
\text { [million } \\
\left.\mathbf{m}^{\mathbf{3}} / \mathbf{y e a r}\right]\end{array}$ \\
\hline $\begin{array}{c}\text { Oder from Bóbr River } \\
\text { to Warta River (right) }\end{array}$ & 17 & 6836.21 & 648.86 & 4.44 & 0.129 & 0.880 \\
\hline The Bóbr River & 16 & 5874.08 & 744.00 & 4.37 & -0.509 & -2.991 \\
\hline $\begin{array}{c}\text { Oder from Barycz River } \\
\text { to Bóbr River (Left) }\end{array}$ & 15 & 4991.06 & 586.4 & 2.93 & -0.149 & -0.746 \\
\hline Barycz River & 14 & 5547.03 & 581.00 & 3.22 & -0.403 & -2.235 \\
\hline $\begin{array}{c}\text { Oder from Nysa } \\
\text { Kłodzka River Barycz } \\
\text { River (right) }\end{array}$ & 13 & 12409.14 & 636.64 & 7.90 & -0.510 & -6.327 \\
\hline Nysa Kłodzka River & 12 & 4570.07 & 752.46 & 3.44 & -0.223 & -1.019 \\
\hline $\begin{array}{c}\text { Oder to Nysa Kłodzka } \\
\text { River (left) }\end{array}$ & 11 & 13435.79 & 727.31 & 9.77 & 0.179 & 2.406 \\
\hline
\end{tabular}


Table 8. A statement of periodicity values (inverses of predominating frequencies) for mean monthly precipitation sequences in the period 1901-2010 by months in upper and middle Oder drainage basins.

\begin{tabular}{|c|c|c|c|c|c|c|c|c|c|c|c|c|c|c|c|c|c|}
\hline \multirow{3}{*}{$\begin{array}{l}\text { Region of water } \\
\text { resources } \\
\text { assessment }\end{array}$} & \multicolumn{12}{|c|}{ Months of the calendar year } & \multicolumn{5}{|c|}{ Periodicity of statistics } \\
\hline & 'I' & 'II' & 'III' & 'IV' & 'V' & 'VI' & 'VII' & 'VIII' & 'IX' & 'X' & 'XI' & 'XII' & Min & $\operatorname{Max}$ & Avg & $S_{d}$ & $C_{v}$ \\
\hline & \multicolumn{17}{|c|}{ [years] } \\
\hline $\begin{array}{l}\text { Oder from Bóbr } \\
\text { River to Warta } \\
\text { River (right) } \\
\end{array}$ & $\begin{array}{l}\text { 足 } \\
\text { 足 }\end{array}$ & 点 & 8 & مٌ & $\stackrel{w}{N}$ & $\stackrel{w}{\oplus}$ & $\underset{\dot{0}}{\omega}$ & 岕 & $\ddot{b}$ & 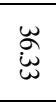 & $\stackrel{N}{\circ}$ & $\begin{array}{l}\omega \\
\dot{\infty}\end{array}$ & 8 & $\stackrel{N}{\stackrel{N}{N}}$ & 电 & $\stackrel{N}{\stackrel{N}{N}}$ & 莣 \\
\hline Bóbr River & $\begin{array}{l}\text { un } \\
\text { 品 }\end{array}$ & 点 & : & : & $\stackrel{w}{\sim}$ & $\stackrel{\omega}{ \pm}$ & $\begin{array}{l}\omega \\
\ddot{\infty}\end{array}$ & $\stackrel{+}{6}$ & $\ddot{\sigma}$ & $\underset{\omega}{\omega}$ & $\stackrel{\sim}{\circ}$ & $\begin{array}{l}w \\
\dot{0}\end{array}$ & 8 & $\underset{N}{\stackrel{w}{\Delta}}$ & $\underset{N}{\stackrel{w}{\Delta}}$ & $\stackrel{\vec{\sigma}}{\sigma}$ & $\stackrel{t}{6}$ \\
\hline $\begin{array}{c}\text { Oder from Barycz } \\
\text { River to Bóbr } \\
\text { River (Left) }\end{array}$ & $\stackrel{\vec{c}}{+}$ & $\begin{array}{l}\text { 点 } \\
\text { 号 }\end{array}$ & 8 & $\stackrel{\vec{A}}{\vec{A}}$ & $\dot{8}$ & $\stackrel{\omega}{ \pm}$ & 岁 & $\underset{\sim}{\sim}$ & $\ddot{\sigma}$ & 岕 & $\stackrel{\sim}{\circ}$ & $\stackrel{\nexists}{\oplus}$ & $\begin{array}{l}\text { n } \\
\text { 崩 }\end{array}$ & $\stackrel{\circ}{\circ}$ & $\ddot{0}$ & $\stackrel{\circ}{\circ}$ & $\begin{array}{l}\text { un } \\
\text { 品 }\end{array}$ \\
\hline Barycz River & $\begin{array}{l}u \\
\stackrel{u}{u}\end{array}$ & $\underset{\sim}{\tilde{u}}$ & $\stackrel{N}{\circ}$ & $\stackrel{\vec{A}}{\vec{A}}$ & $\overline{8}$ & $\tilde{a}$ & $\stackrel{N}{\infty}$ & $\stackrel{\vec{\sigma}}{ }$ & 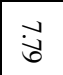 & $\underset{\omega}{\omega}$ & $\stackrel{N}{\circ}$ & $\stackrel{\oplus}{\oplus}$ & $\stackrel{n}{\stackrel{2}{\alpha}}$ & $\stackrel{\underset{\sim}{\sim}}{\Delta}$ & $\stackrel{\underset{N}{\sim}}{.}$ & $\underset{\dot{0}}{\omega}$ & $\stackrel{\vec{t}}{6}$ \\
\hline $\begin{array}{c}\text { Oder from Nysa } \\
\text { Kłodzka River } \\
\text { Barycz River } \\
\text { (right) }\end{array}$ & $\begin{array}{l}\text { 足 } \\
\text { 足 }\end{array}$ & $\ddot{\sigma}$ & $\stackrel{N}{\circ}$ & $\underset{\sim}{\tilde{W}}$ & : & $\stackrel{N}{\alpha}$ & $\stackrel{\sim}{\frac{N}{\infty}}$ & $\stackrel{\vec{U}}{0}$ & $\stackrel{\vec{J}}{\mathrm{~J}}$ & $\stackrel{\sim}{\sim}$ & $\stackrel{N}{\circ}$ & $\stackrel{\sim}{\tilde{J}}$ & $\stackrel{N}{\sigma}$ & $\stackrel{w}{\underline{\sim}}$ & $\stackrel{\overrightarrow{0}}{*}$ & $\stackrel{+}{6}$ & $\stackrel{t}{\sigma}$ \\
\hline $\begin{array}{l}\text { Nysa Kłodzka } \\
\text { River }\end{array}$ & $\begin{array}{l}n \\
\text { 足 }\end{array}$ & $\dot{\vec{\phi}}$ & $\stackrel{\sim}{\circ}$ & $\underset{\sim}{\tilde{w}}$ & $\overrightarrow{8}$ & $\tilde{a}$ & $\stackrel{N}{\ddot{\circ}}$ & $\stackrel{N}{\circ}$ & $\stackrel{\vec{\omega}}{\vec{\omega}}$ & $\stackrel{\sim}{\stackrel{\sim}{\sigma}}$ & $\stackrel{\vec{H}}{\vec{\perp}}$ & $\underset{\sim}{\tilde{w}}$ & $\stackrel{N}{\circ}$ & $\underset{\infty}{\stackrel{\infty}{\triangleleft}}$ & $\vec{ن}$ & $\stackrel{+}{\dot{\theta}}$ & $\stackrel{t}{6}$ \\
\hline $\begin{array}{c}\text { Oder to Nysa } \\
\text { Kłodzka River } \\
\text { (left) }\end{array}$ & $\stackrel{N}{N}$ & $\overrightarrow{\dot{a}}$ & $\stackrel{N}{0}$ & $\ddot{\ddot{A}}$ & : & Na & $\underset{\ddot{o}}{\omega}$ & $\stackrel{\vec{\sigma}}{ }$ & $\stackrel{N}{\circ}$ & $\ddot{\ddot{A}}$ & $\stackrel{\vec{A}}{\vec{\perp}}$ & $\overline{0}$ & 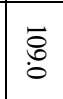 & $\stackrel{N}{=}$ & $\stackrel{ }{\ominus}$ & $\stackrel{\vec{N}}{\ominus}$ & $\stackrel{t}{\sigma}$ \\
\hline
\end{tabular}

Table 9. Slope values of the linear trend in monthly precipitation in a calendar year in the analysed period in upper and middle Oder drainage basins.

\begin{tabular}{|c|c|c|c|c|c|c|c|c|c|c|c|c|}
\hline \multirow{3}{*}{$\begin{array}{c}\text { Region of water resources } \\
\text { assessment }\end{array}$} & \multicolumn{12}{|c|}{ Months of the calendar year } \\
\hline & 'I' & 'II' & 'III' & 'IV' & 'V' & 'VI' & 'VII' & 'VIII' & 'IX' & 'X' & 'XI' & 'XII' \\
\hline & \multicolumn{12}{|c|}{$[\mathrm{mm} / \mathrm{month}]$} \\
\hline $\begin{array}{c}\text { Oder from Bóbr River to } \\
\text { Warta River (right) }\end{array}$ & 0.014 & 0.046 & 0.103 & -0.078 & 0.068 & -0.108 & 0.032 & 0.002 & 0.018 & -0.083 & 0.043 & 0.072 \\
\hline Bóbr River & -0.025 & -0.005 & 0.062 & -0.173 & -0.060 & -0.145 & 0.069 & -0.048 & 0.002 & -0.149 & -0.030 & -0.007 \\
\hline $\begin{array}{c}\text { Oder from Barycz River to } \\
\text { Bóbr River (Left) }\end{array}$ & -0.009 & 0.025 & 0.052 & -0.083 & 0.036 & -0.093 & 0.002 & -0.028 & -0.002 & -0.104 & 0.022 & 0.033 \\
\hline Barycz River & -0.098 & -0.022 & -0.020 & -0.121 & -0.002 & 0.069 & 0.168 & -0.120 & -0.012 & -0.125 & -0.057 & -0.065 \\
\hline $\begin{array}{l}\text { Oder from Nysa Kłodzka } \\
\text { River Barycz River (right) }\end{array}$ & -0.094 & -0.033 & -0.013 & -0.140 & -0.016 & 0.039 & 0.151 & -0.113 & -0.008 & -0.155 & -0.067 & -0.062 \\
\hline Nysa Kłodzka River & -0.052 & -0.004 & 0.025 & -0.093 & -0.019 & 0.061 & 0.190 & -0.152 & 0.033 & -0.137 & -0.049 & -0.026 \\
\hline $\begin{array}{c}\text { Oder to Nysa Kłodzka } \\
\text { River (left) }\end{array}$ & 0.023 & 0.033 & 0.060 & -0.048 & 0.095 & 0.063 & 0.111 & -0.186 & 0.033 & -0.129 & 0.025 & 0.099 \\
\hline
\end{tabular}

\section{Conclusion}

This study discusses the results of a multi-annual analysis of variation of precipitation, performed using the GPCC database of mean monthly precipitation for the upper and middle Oder drainage basins. The analysis includes data for the period 1901-2010 with a spatial resolution of $0.5^{\circ} \mathrm{x}^{\circ} 0.5^{\circ}$ of geographic longitude and latitude. The data is analysed using profiles modelled for individual months of the calendar year and for hydrological years divided into hydrological summers and hydrological winters. 
A cluster analysis is also included, with drought and wet periods indicated. The periodical nature of precipitation is assessed and the trends in climate changes calculated. A taxonomic analysis using the criteria of mean value, standard deviation and coefficient of variation was performed to distinguish two sets of clusters. The first group of clusters is identified as "wet years" The cluster includes 91 years in total, i.e. about $83 \%$ of the analysed period.

The opposite group includes 19 drought years, i.e. about $17 \%$ of the analysed period. The disparity between the numbers of years in those groups indicates a large potential of precipitation as a factor contributing to the origins of floods. Such a significant nonuniformity was not recorded in the upper Vistula drainage basin $(54 \%$ of wet years and $46 \%$ of drought years). The results of the taxonomic analysis are confirmed by the dates of extreme events in the upper and middle Oder drainage basins.

The studied periodicity of monthly precipitation calculated using monthly profiles of calendar years in the period 1901-2010 shows that October is characterised by a long predominating period of repeatability, 36 years, while predominating periods of repeatability for the remaining months amount to $2.1-7.79$ years $(2.1-12.1$ years in the upper Vistula drainage basin). The periods of repeatability: 2.1 years for minimum values, 3.89 years for maximum values, 3.21 years for medium values (in the upper Vistula drainage basin, the minimum value is 3.6 years, the maximum value -36.3 years, the medium value -3.5 years). The values confirm a considerably higher frequency of factors (precipitation) leading to floods in the upper and middle Oder basins. An analysis of predominating periodicity of maximum values in the upper and middle Oder area demonstrates that the periodicity is almost 10 times less than the corresponding characteristic value in the upper Vistula basin, with a comparable periodicity of minimum values. This disparity indicates a higher frequency of extreme factors occurring in the upper and middle Oder drainage basins.

The periodicity of total monthly precipitation calculated using hydrological summer and hydrological winter profiles in the analysed period 1902-2010 equals 2.08 years for the winter season and 2.35 years for the summer season. Such a short predominating period of repeatability of precipitation in the summer and winter seasons does not occur in the upper Vistula drainage basin (13.5 years in the winter season and 36 years in the summer season in the upper Vistula drainage basin).

The trend in climate changes obtained using total monthly precipitation profiles for the hydrological summer is described by linear equations with indicated boundary values of coefficients determined at a 5\% significance level. Over the analysed period 1902-2010, the slope value is negative and varies between $-0.236 \mathrm{~mm} /$ year for November of the hydrological year and $-0.006 \mathrm{~mm} /$ year for July of the hydrological year. The total of precipitation is characterised by a negative trend of $-0.236 \mathrm{~mm} / \mathrm{year}$ in the analysed period of 109 years.

The image of trend in climate changes resulting from monthly profiles of precipitation in calendar summer in the analysed period 1901-2010, as described by its slope, adopts negative and positive values. The months of January, April, June, August, October and November are characterised by a decreasing trend in precipitation while the remaining months by a positive trend. The values vary between -0.129 in October and $+0.108 \mathrm{~mm} /$ month in July.

The trend analyses performed for water-balance upper and middle Oder basins indicate strong negative trends in totals of annual precipitation in the following drainage basins: the Bóbr, the Oder from the Barycz to the Bóbr (1), the Barycz, the Oder from the Nysa Kłodzka to the Barycz (p), the Nysa Kłodzka ( -0.510 to $-0.149 \mathrm{~mm} / \mathrm{year}$ ). The results of analyses performed for the upper and middle Oder drainage basins indicate a drop in precipitation water resources by about $13 \mathrm{Mm}^{3} /$ year, unlike in the upper Vistula drainage 
basin, where great positive trends are identified, in particular in the San, Dunajec and Wisłok drainage basins.

The results of analyses confirm the concerns expressed in the National Water Management Strategy: insufficient water retention and downward trends in available water resources. The strong polarity shown by those analyses indicates the need for developing an effective plan for flood control capacity and compensation of drought phenomena. Both objectives can be achieved by way of rationally planned retention and a reasonable zoning policy.

\section{References}

1. A. Dubicki, H. Słota, J. Zieliński, Seria Atlasy i Monografie, Wydawnictwo IMGW, (1999)

2. B. Kaźmierczak, A. Kotowski, M. Wdowikowski, Ochrona Sěrodowiska, 36, 3, 49-54, (2014)

3. M. Kirschenstein, D. Baranowski, Ser. A. Geografia Fizyczna. 56, 55-72 (2005)

4. B. Twaróg B., IOSR-JESTFT, 10, 10, 50-64 (2016)

5. R. F. Adler, G.J. Huffman, A. Chang, R. Ferraro, P. Xie, J. Janowiak, B. Rudolf, U. Schneider, S. Curtis, D. Bolvin, A. Gruber, J. Susskind, P. Arkin and E. Nelkin, Journal Hydrometeorol, 4, 1147-1167 (2003) 